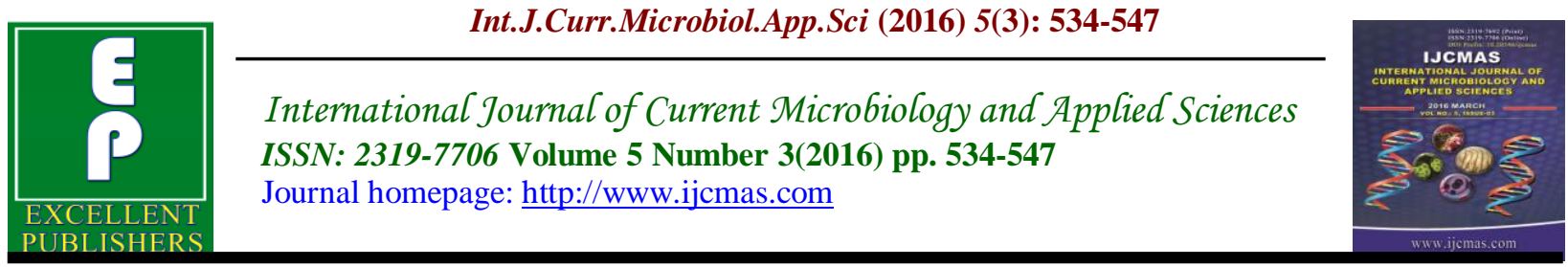

Original Research Article

http://dx.doi.org/10.20546/ijcmas.2016.503.063

\title{
Biodegradation of Diazo Dye, Reactive Blue 160 by Isolate Microbacterium sp. B12 Mutant: Identification of Intermediates by LC-MS
}

\author{
Chetana Roat ${ }^{1}$, Avinash Kadam $^{2}$, Tallika Patel ${ }^{1}$ and Shailesh Dave ${ }^{1 *}$ \\ ${ }^{1}$ Department of Microbiology \& Biotechnology, University School of Sciences, \\ Gujarat University, Ahmedabad-380 009, India \\ ${ }^{2}$ Department of Environmental Engineering, Kyungpook National University, \\ 80 Daehak-ro, Buk-gu, Daegu 702-701, Daegu, Republic of Korea
}

*Corresponding author

\section{Introduction}

The environmental problems created by the textile industry have received increased attention for several decades; the textile industry is one of the largest generations of contaminated effluents (Solis et al., 2012). The discharge of dyes containing effluents in to the environment is of great concerned due to colour, toxicity, mutagenicity and carcinogenicity of dyes. Textile dyes have always been considered in the context of recalcitrant xenobiotic compounds in water and soil ecology (Daneshwar et al., 2007; Dafale et al., 2010)

Reactive dyes consist of a chromophoric system (e.g azo, anthraquinone, phthalocyanine), the anchor groups and the group which increases the water solubility (mostly $-\mathrm{SO}_{3}{ }^{-}$). The decolorization of 
reactive dyes results in destroying the chromophoric system, and formation of toxic/nontoxic byproduct (Bansal et al., 2012). The toxic byproduct must be properly treated before disposing into the environment. Advanced oxidation methods such as sonolysis, fenton oxidation, ozonation, photochemical oxidation and electrochemical destruction are available for the treatment of dye containing effluents but biodegradation is considered as an economic one compared to the above mentioned processes (Dos Sontos et al., 2007). The use of microbes that possess the ability to decolourize synthetic dyes including bacterial strains and fungi (Liu et al., 2004; Hadibarata et al., 2011a; Hadibarata et al., 2012b).

For decolourization and degradation many techniques are practiced that includes bioengineering of organisms. The technique, like, random mutagenesis, is used to induce mutation in organisms for better distinctiveness (Sandesh et al., 2008). Mutagens such as UV irradation, Acridine orange are employed for inducing mutation (Chandra et al., 2008 and Chen et al., 2001). Improvement of the microbial strain by subjecting the genetic material to physical and chemical mutagenic agents offers furthermost opportunity for cost reduction without significant capital outlay (Stanbury et al., 1995; Lofty et al.,; 2007).

The genus Microbacterium was described by Orla-Jensen (1919) and comprises a diverse collection of yellow pigmented gram positive, nonspore forming rods that were isolated from various environmental habitats like soil, water and steep liquor (Young et al., 2010). Microbacterium amylolyticum sp. nov., isolated from soil from an industrial waste (Anand et al., 2012). At present, the genus Microbacterium comprises 83 species (www.bacterio.cict.fr/m/microbacterium.ht $\mathrm{ml})$.
Reactive dye Blue 160 is a diazo commercial dye, commonly used for dyeing cotton, viscose, flex and jute but not suitable for silk, polyesters and wool. Very few studies on the decolourization and degradation of B160 have been reported.

In the present study, we first time report the use of Microbacterium sp. B12 for the decolourization and degradation of a Reactive Blue 160. Effect of physicochemical parameters such as temperature, $\mathrm{pH}$ and agitation has been investigated to optimize the dye decolourization. The mutagenesis approach has been made to improve the efficiency of the decolourization by using UV irradiation and acridine orange mutagenes. Used LC-MS techniques to identify various intermediates. Furthermore the toxicity of the dyes both before and after the treatment with Microbacterium sp. B12 was evaluated by utilizing Phaseolus aureus seeds as a bioindicator.

\section{Materials and Methods}

\section{Dyes, chemical and media}

Diazo dye Reactive Blue 160 (RB160) (C.I. No. 137160) was procured from the Ahmadabad dyeing and printing industry, Ahmedabad, Gujarat, India. NADH was purchased from Sigma Chemical Company (USA). Nutrient broth was obtained from HiMedia Laboratory, India. All the chemicals used in the study were of analytical grade.

\section{Strain Isolation and Culture Condition}

Microorganisms used in this study were isolated from the soil samples of textile industry in Ahmadabad, Gujarat. The soil sample was added $1 \% \mathrm{w} / \mathrm{v}$ in nutrient broth containing RB160 $250 \mathrm{mg} / \mathrm{l}$ and incubated at 
$32 \pm 2^{\circ} \mathrm{C}$ temperature under microaerobic as well as aerobic conditions at $150 \mathrm{rpm}$ conditions. After $24 \mathrm{~h}$ of incubation, $1.0 \mathrm{ml}$ of the culture was serially diluted and $0.1 \mathrm{ml}$ was withdrawn from $10^{-5}$ dilutions and inoculated by spread plate method on the nutrient agar plates containing $250 \mathrm{mg} / \mathrm{l}$ RB160. After $24 \mathrm{~h}$ of incubation at optimum temperature, the colonies were screened for their ability to form a clear zone around them. The selected colony with highest zone size was selected, isolated and subculture in nutrient broth containing 250mg/l RB160. Morphological and biochemical test were carried out to identify the selected organism.

\section{Identification of Bacterial Isolate}

Bacterial cells of strain B12 were collected by centrifugation at $10,000 \mathrm{~g}$ for $10 \mathrm{~min}$ and subjected to sequential digestion by lysozyme of $2.5 \mathrm{mg} / 1,37{ }^{\circ} \mathrm{C}$ for $1 \mathrm{~h}$ and proteinase $\mathrm{K}$ was $20 \mathrm{mg} / \mathrm{l}$ in $1 \% \mathrm{SDS}, 55^{\circ} \mathrm{C}$ for $1 \mathrm{~h}$, followed by incubation in $1 \% \mathrm{CTAB}$ and $0.7 \mathrm{M} \mathrm{NaCl}$ at $65{ }^{\circ} \mathrm{C}$ for $15 \mathrm{~min}$. After extraction with phenol/chloroform, the recovered DNA was precipitated with ethanol and then dissolved in ddH2O. The obtained product was amplified using forward primer 27f 5' AGAGTTTGATCMTGGCTCAG-3' and reverse primer 1492r 5'CGGYTACCTTGTTACGACTT-

3'.Sequence data analysis was done using Chromas Pro and Sequencing Analysis software.The sequence was input to NCBI to identify it by BLAST search.

\section{Phylogenetic Tree Construction}

All the sequences were compared with $16 \mathrm{~S}$ rRNA gene sequences available in the GenBank databases by BLASTn search and the multiple sequence alignments of partial $16 \mathrm{~S}$ rRNA gene sequences from 1 to $712 \mathrm{bp}$ were aligned using CLUSTALW, version 1.8 (Tompson et al.,1994). Phylogenetic trees were constructed from evolutionary distances using. The Neighbor-Joining method implemented through NEIGHBOR (DNADIST) from the PHYLIP version 3.61packages (Felsenstein JP 1993). The robustness of the phylogeny was tested by bootstrap analysis using 100 iterations. Trees generated were analysed with the TREEVIEW program (Page RDM 1996). Accession numbers of all isolate can be viewed in a respective phylogenetic tree.

\section{Inoculum Preparation}

A loop full cell growth from the preserved slant was inoculated in $100 \mathrm{ml}$ nutrient broth and incubated on an orbital shaker agitating at $150 \mathrm{rpm}$ and $32 \pm 2{ }^{\circ} \mathrm{C}$ temperature for 24 h. For RB160 dye decolourization study, $10 \%(\mathrm{v} / \mathrm{v})$ of the actively growing culture having $3 \times 10^{8}$ cells $/ \mathrm{ml}$ was used as inoculum in all the further experiments.

\section{Optimization of Physico-Chemical Parameters}

Temperature, $\mathrm{pH}$ and agitation were optimized during the experimentation for maximizing decolorizing efficiency of the isolate. Effect of different incubation temperature and $\mathrm{pH}$ for dye $\mathrm{RB} 160$, were carried out in $250 \mathrm{ml}$ Erlenmeyer flasks, containing $80 \mathrm{ml}$ nutrient broth, $10 \mathrm{ml}$ dye $2.5 \mathrm{mg}$ RB160 and the bacterial culture $10 \mathrm{ml}$ having $3 \times 10^{8}$ cells $/ \mathrm{ml}$ contained Optical Density 1 at $604 \mathrm{~nm}$.Flasks were incubated at 25,35 and $45{ }^{\circ} \mathrm{C}$ temperature. Effect of $\mathrm{pH}$ was studied at 3, 5, 7 and 9 and the influence of the initial decolourization experiment was also carried out under aerobic and microaerobic conditions. Each experiment was carried out in triplicate.

\section{Mutagenesis Induction}

The cells were harvested from the culture medium by centrifugation at $10,000 \mathrm{~g}$ for 10 
min. The cell pellet was washed with distilled water and resuspended in sterile deionised water. The colony counting method was used for bacterial count and the count was adjusted to $2.34 \times 10^{7} \mathrm{CFU} / \mathrm{ml}$. For UV mutagenesis, $15 \mathrm{ml}$ of cell suspension was taken and placed under a germicidal lamp in a sterile petri -plate, distance of $30 \mathrm{~cm}$ and exposed to UV light upto a $5 \mu$ Joule $^{-\mathrm{mm} 2}$ dose $(260 \mathrm{~nm})$ for the induction of a mutant. The time of exposure was varied from $30 \mathrm{sec}$. to $120 \mathrm{sec}$. For chemical mutation, the distilled water washed cell pellet was redissolved in $20 \mathrm{ml}$ of $0.5,10,30 \mu \mathrm{g} / \mathrm{ml}$ concentration of acridine orange and were shaken well for 30 min in an orbital shaker. Samples were taken at every $300 \mathrm{sec}$. and studied. The viability of cell count was carried out by the spread plate technique and \% survival was calculated using Equation:

$\mathrm{S}=\left(\mathrm{N}_{\mathrm{i}}-\mathrm{N}_{\mathrm{d}} / \mathrm{N}_{\mathrm{i}}\right) \times 100$

Where $\mathrm{S}$ is the \% survival, $\mathrm{N}_{\mathrm{i}}$ is the initial viable cell count and $\mathrm{N}_{\mathrm{d}}$ is the viable cell count after mutation.

\section{Preparation of Cell Free Extract}

The cells of Microbacterium sp. B12 were grown for $24 \mathrm{~h}$ under microaerobic condition at $32 \pm 2{ }^{\circ} \mathrm{C}$ in $100 \mathrm{ml}$ sterile nutrient broth, centrifuged at 10,000 $\mathrm{g}$ for 10 min. The culture supernatant was used as an extracellular enzymes. Potassium phosphate buffer $50 \mathrm{mM}, \mathrm{pH} 7.4$ was used to suspended the cells and sonicated (Labsonic®M, Sartrious, Germany) at an output of 60 A with seven strokes each of 30 sec. with a $120 \mathrm{sec}$. interval at $4{ }^{\circ} \mathrm{C}$. The obtained extracts were used as a source of the intracellular enzyme after centrifugation at $10,000 \mathrm{~g}$ for $10 \mathrm{~min}$ at $4{ }^{\circ} \mathrm{C}$. All the enzyme assays were run in triplicates and average rates were calculated.

\section{Enzyme Activity}

Azo reductase assay and NADH-DCIP (2, 6 dichloro-phenol indophenol) reductase activity were determined using the procedure reported earlier by Lade et al., (2012).One unit of enzyme activity was defined as change in absorbance unit per $\mathrm{ml}$ of enzyme (Mate at al. 2012). Laccase assay was carried out by modified procedure of Senan and Abraham, (2004). All enzyme activities were assayed under ambient conditions and performed in triplicates.

\section{Biodegradation Analysis}

The decolourization assayed was monitored by measuring the change in absorbance maxima of the dye at $\lambda_{\max } 604 \mathrm{~nm}$ using the UV-vis spectrophotometer. The colour removal was calculated as percent decolourization and was expressed as:

Decolourization $(\%)=[($ Initial Absorbance - Final Absorbance)/Initial Absorbance] X 100

The decolourized culture medium was centrifuged at $10000 \mathrm{~g}$ for $10 \mathrm{~min}$ and supernatant was collected and extracted with ethyl acetate evaporate it and re-dissolved in HPLC grade methanol. The mobile phase consisted of water: methanol (60:40) with flow rate $1 \mathrm{ml} / \mathrm{min}$. The purity was checked by UV detector at $254 \mathrm{~nm}$, isocratic system and 10 min run time. LC-MS was carried out by LCMS-2010SA, Shimadzu, Japan. Mass spectra was obtained using an ion trap mass spectrometer fitted with an electronic spray (ESI, a Thermo Finnigan LCQ-DUO, USA) interface operated in a negative ionization mode with a spray voltage of $4.5 \mathrm{KV}$, at a capillary temperature of $275^{\circ} \mathrm{C}$, sheath gas at $40 \mathrm{AU}$ (arbitrary unit) and auxiliary gas at $26 \mathrm{AU}$. 


\section{Phytotoxicity Studies}

To assess the toxicity of dye RB160 and its metabolite produced after decolourization by Microbacterium sp. phytotoxicity tests were carried out on Phaseolus aureus. The ethyl acetate extracted products of dye $250 \mathrm{mg} / \mathrm{l}$ RB160 was dried and dissolved in sterile distilled water for phytotoxicity studies. Toxicity effect was measured in terms of percent inhibition in germination, lengths of the plumule and radical of the Phaseolus aureus.

Germination $(\%)=\frac{\text { No. of seeds germinated } \times 100}{\text { No. of seeds sowed }}$

\section{Statistical Analysis}

Data were analysed by one way analysis of variance (ANOVA) with the tukey-Kramer multiple comparisons test.

\section{Results and Discussion}

Screening, Isolation and Identification of decolourizing bacteria

Soil and wastewater samples contaminated with dye RB160 from dye manufacturing industry facilitated isolation of twelve morphologically distinct isolates showing decolourization zone of $2-10 \mathrm{~mm}$ on nutrient agar plates containing $250 \mathrm{ppm}$ RB160. The isolate 1 , which gave the largest ratio of decolourisation zone: colony diameter of 1.82 for a colony size of 3-4 $\mathrm{mm}$ was selected for further study. The colony of isolated bacteria was yellowpigmented, opaque with moist consistency and smooth texture. The isolate was grampositive, showed positive test for carbohydrate fermentation, lead acetate, $\mathrm{H}_{2} \mathrm{~S}$ production, casein and lipid hydrolysis, citrate utilization and triple sugar iron and negative test for nitrate reduction, indole production, gelatin/hydrolysis, starch hydrolysis, decorboxylation, deamination, urea hydrolysis and ammonia production Based on these results the isolate was tentatively identified as Microbacterium sp. Sequence analysis of $16 \mathrm{~S}$ rRNA gene showed that isolated strain had highest similarity of only $97 \%$ with the species Microbacterium paraoxydans, which has not been reported for decolorizing ability for any dyes. Moreover the species is reported in the blood of leukemia patient (Laffineur et al., 2003). Thus the isolate could be other species of Microbacterium. Some species of Microbacterium are also isolated from oil polluted soil (Sheng et al., 2009). Levels of less than $97 \%$ similarity were found in the type strains of all other recognized Microbacterium species. Based on the phenotypic characteristics and phylogenetic analysis, strain B12 was designated as a species of Microbacterium ( Figure 1). The16S rRNA sequence of Microbacterium sp.B12 has been deposited in GeneBank with the accession number JX984606.

\section{Optimization of Physico-Chemical Factors}

It is evident from Figure 2a that when temperature raised from 25 to $35^{\circ} \mathrm{C}$ there was an inconsistent trend in the decolourization by isolate, but when the temperature was raised to 45 , it was observed that the decolourization was suddenly declined this might be due to the loss of cell viability or deactivation of the enzymes responsible for decolourization at higher temperature (Ponraj et al., 2011). Maximum decolourization for the dyes RB160 was observed at $35^{\circ} \mathrm{C} \pm 2{ }^{\circ} \mathrm{C}$. Least decolourization was observed at $45^{\circ} \mathrm{C}$ was $24 \%$ after $96 \mathrm{~h}$ of incubation. Temperature is very important parameter for wastewater treatment. Selected isolate was mesophilic bacteria because it showed best decolourization at the temperature $35^{\circ} \mathrm{C} \pm$ 
$2^{\circ} \mathrm{C}$. The mesophilic range is traditionally used (Varel et al., 1980) since it is generally thought that maintaining high temperature would be uneconomical, while degradation within the psychrophilic range is too slow (Mahmood et al., 2011).

The best decolourization for dye RB160 was at $\mathrm{pH} 5$ with $94 \%$ in $96 \mathrm{~h}$. Moreover, from the obtained data it can be inferred that Microbacterium. sp. exhibited more than 90\% decolourization for dye RB160 over a broad range of $\mathrm{pH} 3$ to 9 . Decrease in the decolourization for dye RB160 was more towards alkaline $\mathrm{pH}$ compare to acidic $\mathrm{pH}$ under study. So the study indicates that the acidic $\mathrm{pH}$ is less detrimental compare to alkaline $\mathrm{pH}$. Figure $2 \mathrm{~b}$. The microaerobic condition as compared to aerobic conditions, which is an oxygen limiting condition, was found to better for decolourization of RB160 Figure $2 \mathrm{c}$.

\section{Mutagenesis}

The dose-response analysis for the UV mutagenesis and acridine orange of Microbacterium sp. was done and the \% survival values are shown in Table 1 . The dose of UV was assessed by time, $30 \mathrm{sec}$ of UV radiation treated strain decolourized $95 \%$ of RB160 in $72 \mathrm{~h}$ and $0.5 \mu \mathrm{g} / \mathrm{ml}$ of acridine orange showed $94 \%$ decolourization in $72 \mathrm{~h}$ indicated that the enhancement in decolorization of RB160 was due to the bacteria strain after mutated. The physical mutagens are time dependent and chemical mutagens dose dependent (Mouurti et al., 2010). Hence, here, the UV radiation and acridine orange reduced the time for dye decolourization by $24 \mathrm{~h}$ the survival capacity of the organism was decreased drastically with an increase in dosage and this is due to lethal DNA damage by UV irradiation. The frame shift mutation in DNA, due to acridine orange was responsible for the DNA damage. Since the self DNA repair mechanism fails in certain cases, the mutation caused by the acridine orange was permanent. (Gopinath $e t$ al., 2009).

\section{Enzyme Analysis}

In the present study, significant induction of laccase, azoreductase and NADH-DCIP reductase activities suggested their involvement in the dye degradation shown in Table 2. In the same contest, the inductive pattern of reductase was reported during the degradation of triazo acid black 210 by Providencia sp. SRS82. (Agrawal et al., 2014).

\section{Biodegradation Analysis}

Conformation of biodegraded product of RB 160 by LC-MS. During the degradation there was asymmetric cleavage of azo bond in RB160 resulting in the formation of six known metabolites 2-[(4-chloro-1,3,5triazin-2yl) amino-5-4\{ (4-choro-6-\{(3 sulphophenyl)amino -1,3,5-triazine-2-

yl)amino)] benzene-1,4-disulphonic acid $\mathrm{m} / \mathrm{z}$ value 667,3 -[ $\{4$-chloro-1,3,5-triazin-2$\mathrm{yl}$ \}amino]benzene sulfonic acid $\mathrm{m} / \mathrm{z} 286,2$ amino-5 [(4-chloro-1,3,5-triazine-2-yl) amino] benzene-1,4-disulfonic acid $\mathrm{m} / \mathrm{z} 381$, 3,5-diamino-4-hydroxybenzenesulfonic acid $\mathrm{m} / \mathrm{z}$ 204, 2-amino-5[(4-chloro-1,3,5-triazine2-yl) amino]benzene sulfonic acid $\mathrm{m} / \mathrm{z} 301$, 3-amino-4-hydroxybenzenesulfonic acid $\mathrm{m} / \mathrm{z}$ 189 and two unknown metabolites $2[\{(3$ amino-2-hydroxy-5 sulfophenyl) diazenyl(phenyl) methyl $\}$ diazenyl]-5sulfobenzoic acid and 2\{amino(phenyl) methyl \}diazenyl-5-sulfobenzoic acid (Figure 3). Earlier the LC-MS was used to find different intermediates produced in diazo dye degradation by Soybean Peroxidase by Kalsoom et al., (2013). 
Table.1 Effect of Physical and Chemical Mutagen on B160

Decolorization by Microbacterium sp. B12

\begin{tabular}{|c|c|c|c|c|c|c|c|c|c|}
\hline \multicolumn{10}{|c|}{ Decolourization of RB $160(\%)$ at Time (h) } \\
\hline \multicolumn{5}{|c|}{ UV (seconds) Treatment } & \multicolumn{5}{|c|}{ Acridine orange $(\mu \mathrm{g} / \mathrm{ml})$ Treatment } \\
\hline & 0 & 24 & 48 & 72 & & 0 & 24 & 48 & $\overline{772}$ \\
\hline $\mathbf{0 . 0}$ & $5.0 \pm 1.7$ & $25 \pm 2.1$ & $48 \pm 0.88$ & $70 \pm 1.2$ & $\mathbf{0 . 0}$ & $3.0 \pm 2$ & $24 \pm 2.3$ & $50 \pm 1.66$ & $72 \pm 2.7$ \\
\hline 30 & $4.8 \pm 2.8$ & $95 \pm 2.1$ & $48 \pm 1.2$ & $26 \pm 1.98$ & 0.5 & $3.3 \pm 2.4$ & $94 \pm 3.2$ & $54 \pm 3.1$ & $25 \pm 1.15$ \\
\hline 60 & $5.2 \pm 2.3$ & $25 \pm 1.15$ & $44 \pm 2.8$ & $57 \pm 0.64$ & 10 & $2.9 \pm 1.7$ & $22 \pm 0.54$ & $32 \pm 1.89$ & $65 \pm 3.2$ \\
\hline 120 & $5.0 \pm 2.6$ & $20 \pm 0.88$ & $22 \pm 2.1$ & $37 \pm 1.11$ & 30 & $3.1 \pm 2.1$ & $20 \pm 0.76$ & $22 \pm 1.32$ & $45 \pm 1.1$ \\
\hline
\end{tabular}

Values are mean of three experiments \pm standard deviations

Table.2 Enzyme Activity during Decolourization of RB160 by Microbacterium sp.B12

\begin{tabular}{lll}
\hline & Enzyme activity & \\
\hline Enzymes & Control & $\mathrm{RB} 160$ \\
& $(\mathrm{U} / \mathrm{mg} / \mathrm{ml} / \mathrm{min})$ & $(\mathrm{U} / \mathrm{mg} / \mathrm{ml} / \mathrm{min})$ \\
\hline Laccase $^{\mathrm{a}}$ & $0.101 \pm 0.78$ & $0.172 \pm 1.6$ \\
NADH-DCIP reductase $^{\mathrm{b}}$ & $5.263 \pm 2.3$ & $8.263 \pm 1.1$ \\
Azo-Reductase $^{\mathrm{c}}$ & $1.95 \pm 0.81$ & $3.26 \pm 2.2$ \\
\hline
\end{tabular}

Enzyme activity:

${ }^{\mathrm{a}} \mu \mathrm{M}$ of ABTS Oxidized $\mathrm{ml}^{-1} \mathrm{~min}^{-1}$

${ }^{\mathrm{b}} \mu \mathrm{g}$ of DCIP reduced $\mathrm{min}^{-1} \mathrm{mg}-1$

${ }^{c} \mu \mathrm{g}$ of methyl red reduced $\mathrm{min}^{-1} \mathrm{mg}^{-1}$

Control= enzyme extracted from culture medium without dye after $24 \mathrm{~h}$; Test $=$ enzyme extracted from the dye decolourized culture medium after $24 \mathrm{~h}$. Values are mean of three experiments \pm SD. Percent induction calculated from mean values.

Table.3 Phytotoxicity of RB160 and its Metabolites Formed after Degradation by Microbacterium sp. B12

\begin{tabular}{llll}
\hline Parameters & \multicolumn{2}{l}{ Toxicity effect on Phaseolus aureus } \\
& \multicolumn{3}{l}{} \\
\cline { 2 - 4 } & Distilled water & RB160 & RB160 metabolite \\
\hline Germination (\%) & 95 & 25 & 86 \\
Plumule $(\mathrm{cm})$ & $9.8 \pm 0.6^{\mathrm{ab}}$ & $3.9 \pm 0.8^{\mathrm{a}}$ & $8.99 \pm 0.99^{\mathrm{b}}$ \\
Radicle $(\mathrm{cm})$ & $3.67 \pm 0.9^{\mathrm{ab}}$ & $0.29 \pm 0.5^{\mathrm{a}}$ & $2.32 \pm 1.37^{\mathrm{b}}$ \\
\hline
\end{tabular}

Values are mean of three experiments. Seeds germinated (in both plumule and radicle growth) in Dye RB160 and Dye RB 160 metabolite is significantly different from the seeds germinated in distilled water at $\mathrm{P}<0.05$, by one-way analysis of variance (ANOVA) with the TukeyeKramer comparison test 
Fig.1 Phylogenetic Tree of the Microbacterium Sp.B12 and Related Organisms

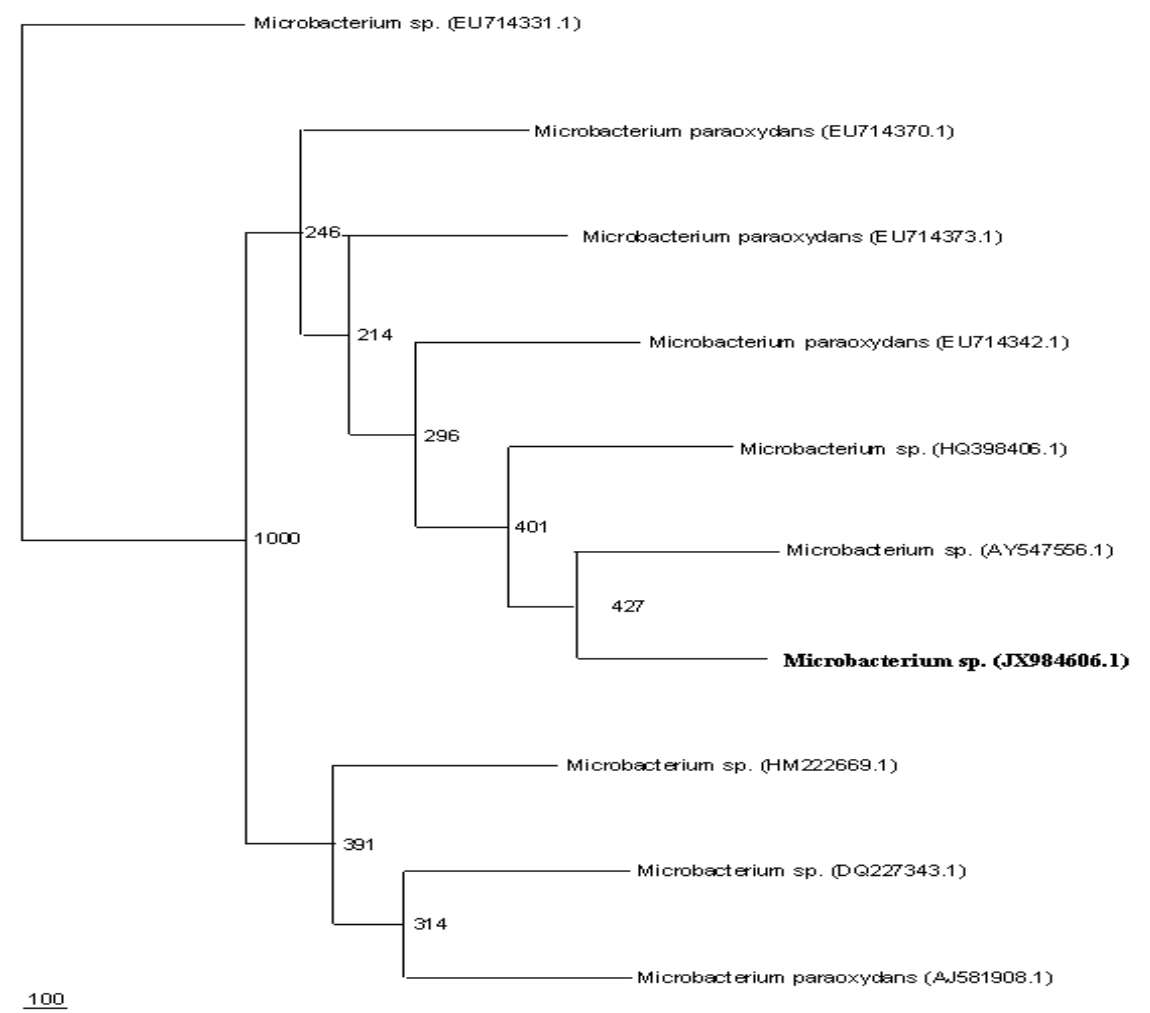

Fig.2 Effect of Physico-chemical Factors on Decolourization of B160 by Microbacterium sp. B12 (a) Incubation Temperature, (b) Initial pH. (c) Aerobic/Microaerobic

(A)

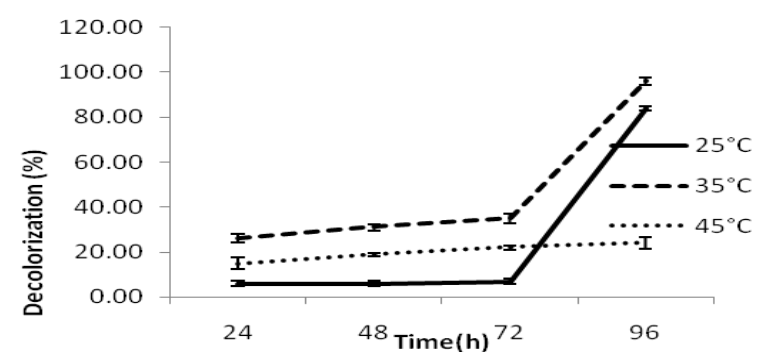

(B)

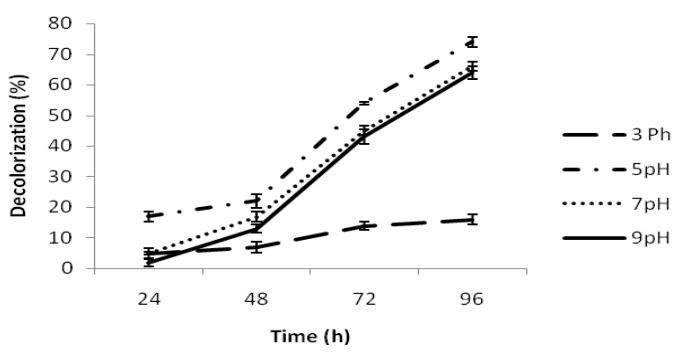


(C)

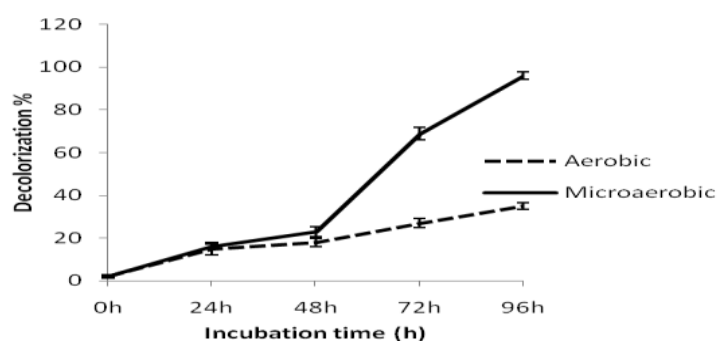

Fig.3 Proposed Pathway for RB160 Degradation by Microbacteium sp. B12

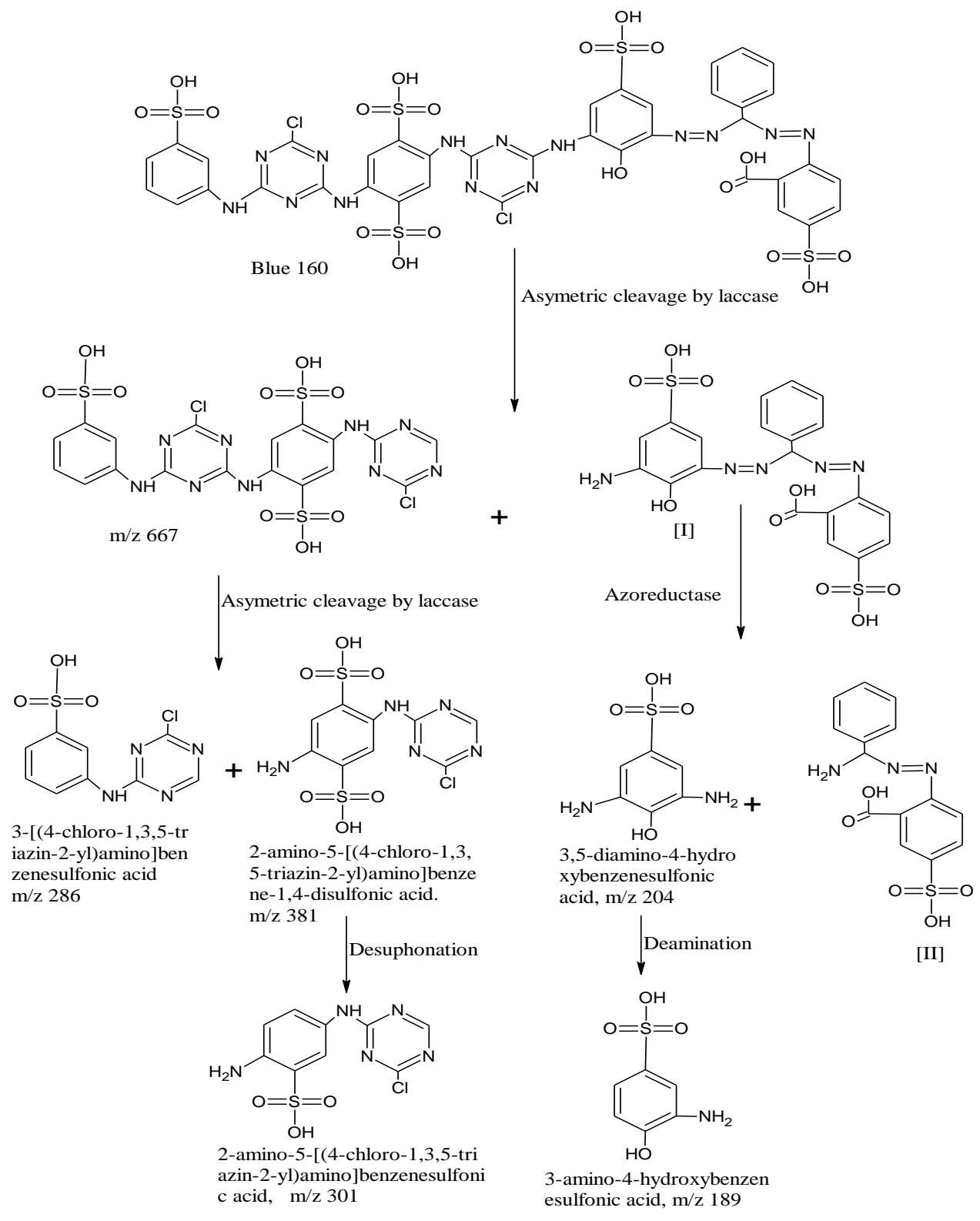


Fig.S1 HPLC Chromatogram of RB160 (a) Dye and its (b) Metabolites after $24 \mathrm{~h}$
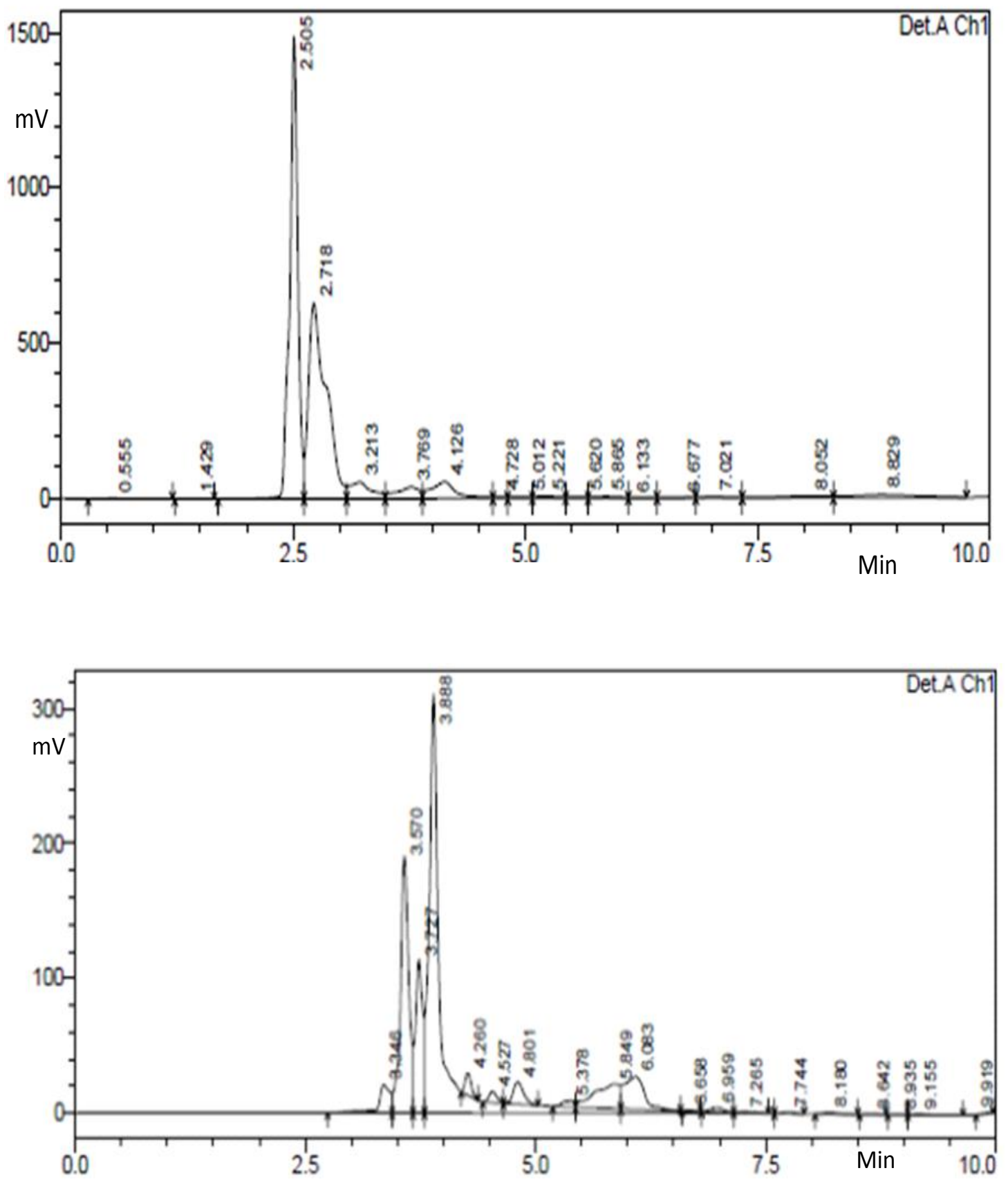
Table.S1 LC-MS Spectral Data of Metabolites Obtained after Degradation of RB160 by Microbacterium sp. B12

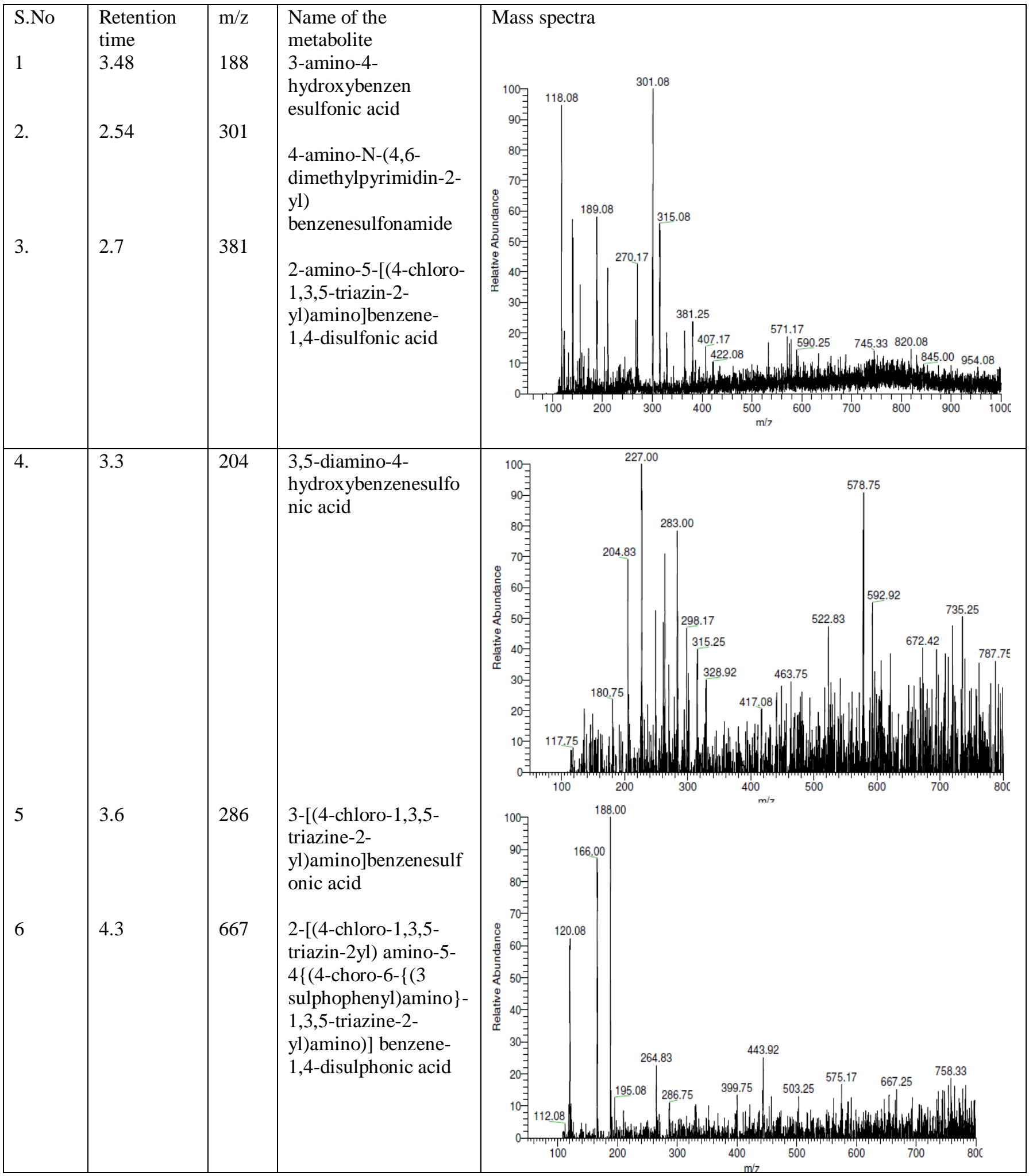




\section{Phytotoxicity Studies}

Use of bioassays such as phytotoxicity for monitoring the toxic effect of dyes as well as its metabolites in plants was suggested by many researchers (Lade et al., 2012). Seed germination and plant growth bioassays are the most common techniques used to evaluate the phytotoxicity. In this case, the phtotoxicity study revealed that there was an inhibition of $25 \%$ germination in a solution containing $1000 \mathrm{mg} / \mathrm{l}$ of RB160 shown in Table 3. This study suggests that the dye RB160 was toxic to plants, while the metabolites formed after degradation were less toxic, which signifies the detoxification of dyes by Microbacterium. sp. B12, these results underlines the importance of Microbacterium for bioremediation of diazo dyes RB160 in terms of both decolourization and detoxification.

The ability of Microbacterium sp. B12 to decolourize the diazo reactive dye RB160 under a broad range of temperature, $\mathrm{pH}$, agitation, suggested that the isolated strain could be useful in biological treatment of industrial wastewater. UV-visible spectroscopy analysis confirmed decolourization, HPLC and LC-MS analysis confirmed degradation of RB160.

In conclusion, we found that the decolourization and degradation of RB160 have not been reported by single microbial isolate. The present work showed decolourization and degradation of RB160 by Microbacterium sp. B12 within $96 \mathrm{~h}$, at pH 5.0 and $35{ }^{\circ} \mathrm{C}$ under microaerobic conditions. The process could be further effectively developed by using physical and chemical mutagens for improved decolourization in less time 72h. HPLC and LC-MS analysis showed formation of new metabolites. Phytotoxicity study proves that, strains have potential to degrade dye in to non- toxic compounds. To our knowledge, this is first time reported the decolourization and degradation of reactive dye RB160 by Microbacterium sp. B12.

\section{Acknowledgement}

The authors acknowledge the University Grant Commission, New Delhi, India for providing Postdoctoral Fellowship with Ref. No.31-78(SC)/2009(SA-III) to one of the author.

\section{References}

AnandS, Bala K, Saxena A, Schumann P, Lal R (2012) Microbacterium amylolyticum sp. nov., isolated from soil from an industrial waste site. Int J Syst Evol Microbiol 62:2114-2120.

Agrawal S, Tipre D, Patel B, Dave S (2014) Optimization of triazoAcid Black 210 dye degradation.By Providencia $s p$. SRS82 and elucidation of degradation pathway. Process Biochem 49:110-119

Bansal P, Sud D (2012) Photodegradation of commercial dye, CI Reactive Blue160 using $\mathrm{ZnO}$ nanopowder: Degradation pathway and identification of intermediates by GC/MS. Sep Purif Technol 85:112119.

Chandra M, Kalra A, Sangwan, NS, Gaurav SS, Darokar, MP, Sangwan RS (2008) Development of mutant of trichodermacitrinoviride for enhanced production of cellulases. Bioresour. Technol. 100 :1659-1662.

Chen H, Jin X, Zhu K, Yang R (2002) Photocatalytic oxidative degradation of acridine orange in aqueous solution with polymeric metalloporphyrins Water Research 36:4106 .

Dafale N, Agarwal L, Kapley A, Meshram S, Purohit, H, Wate S (2010) Selection 
of indicator bacteria based on screening of $16 \mathrm{~S}$ rDNAmetagenomics library from a two- stage anoxic-oxic bioreactor system degrading azo dyes. Bioresour Technol 101:476-484.

Daneshvar N, Ayazloo M, Khataee AR, Pourshassan, M (2007) Biological decolorization of dye solution containing malachite green by Microalgae cosmarium sp. Bioresour Technol. 98:1176-1182 .

Dos Sontos, AB, Cervantes FJ, Van Lier JB (2007) Review paper on current technologies for decolourization of textile wastewaters: perspectives for anaerobic biotechnology. Bioresour Technol 98:2369-2385.

Felsenstein JP (1993) Phylogeny Inference Package Department of Genetics. University of Washington Seattle. Distribution 3:57.

Gopinath KP, AsanMeera Sahib H, Muthukumar K, Velan M (2009) Improved biodegradation of congo red by using Bacillus sp. Bioresour Technol 100:670-675.

Hadibarata T, Yusoff ARM, Kristanti RA (2011a) Decolorization and Metabolism of anthraquionone-type dye by laccase of white-rot fungi Polyporussp. S133. Water Air Soil Pollut 223:933-941.

Hadibarata T, Yusoff ARM, Aris A, SalmiatiHidayat $T$, Kristanti RA (2012b) Decolorization of Azo, triphenylmethane and anthraquinone dyes by laccase of a newly isolated Armillariasp. F022. Water Air Soil Pollut 223:1045-1054 .

Kalsoom U, Ashraf SS, Mohammed AM, Muhammad AR, Bhatti HN (2013) Mechanistic study of a diazo dye degradation by Soybean Peroxidase. Chem Cent J 7:93.

Lade SH, Waghmode TR, Kadamb AA, Govindwar SP (2012) Enhanced biodegradation and detoxification of disperse azo dye Rubine GFL and textile industry effluent by defined fungal-bacterial consortium. Int Biodeter Biodegr 72:94-107.

Laffineur K, Avesani V, Cornu G, Charlier J, Janssens M, Wauters G, Delmée M (2003) Bacteremia due to a novel Microbacterium Species in a patient with leukemia and description of Microbacteriumparaoxydans sp. nov. J Clin Microbiol 41:2242-2246 .

Liu W, Chao Y, Yang X, Bao H, Qian S (2004) Biodecolourization of azo, anthraquinonic and triphenylmethane dyes by white-rot fungi and a laccase secreting engineered strain. J Ind Microbiol Biotechnol 31:127-132.

Lotfy WA, Ghanem KM, EI-Helow ER (2007) Citric acid production by a novel Aspergillusniger isolate:I. Mutagenesis and cost reduction studies. Bioresour Technol 98:34643469.

Mate MS, Pathade G (2012) Biodegradation of C.I Reactive red 195 by Enterococcus faecalisstrain YZ66. World J Microbiol Biotechnol 28: 815-826.

Mahmood S, Arshad M, Khalid A, Nazli $\mathrm{ZH}$, Mahmood T (2011) Isolation and screening of azo dye decolorizing bacterial isolates from dyecontaminated textile wastewater. Soil Environ 30:7-12.

Moutri B, Charya MAS (2010) Influence of physical and chemical mutagenes on dye decolorization Mucormucedo. AfrJ Microbiol Res 4:1808-1813.

Orla-Jensen S (1919) The lactic acid Bacteria: Host and Son. Copenhagen Denmark

Page RDM, TreeView (1996) An application to display phylogenetic trees on personal computer. Comput Appl Biosci 12:357-358 . 
Ponraj M, Gokila K, Zambare K (2011). Bacterial decolorization of textile dyeorange 3R .Int J Adv Biotechno Res $1: 168-177$

SandeshKamath B, Vidhyavathi R, Sarda R, Ravishankar GA (2008) Enhancement of Caratenoids by mutation and stress induced carotenogenic genes in Haematococcus pluvialis mutant. BioresourTechnol 99:8667-8673

Senan RC, Abraham TE (2004) Bioremediation of textile azo dyes by aerobic bacterial consortium. Biodegradation 15:275-280.

Sheng XF, HeL HL, Zhou L, Shen YY (2009) Characterization of Microbacterium sp. F10a and its role in polycyclic aromatic hydrocarbon removal in low-temperature soil.Can J Microbiol 55:529-535.

Solis M, Solis A, Perez HI, Manjarrez N, Flores M (2012) Microbial decolourization of azo dyes. A Review. Process Biochem 47: 17231748

Stanbury PF, WhitakerA, Hall SJ (1995)
Fermentation economics: In Principles of fermentation technology. Oxford UK: Pergamann Press p: 331-341.

Thompson JD, Higgins DG, Gibson TJ, Clustal W(1994) Improving the sensitivity of progressive multiple sequences alignment through sequence weighting, position-specific gap penalties and weight matrix choice. Nucleic Acids Res 22:4673-4680

Varel VH, Hashimoto AG, Chen YR (1980) Effect of temperature and retention time on methaneproduction from beef cattle waste. Appl Environ Microbiol., 40:217-222.

Young CC, Busse HJ, Langer S, Chu JN, Schumann P, Arun AB, Shen FT, Rekha PD, Kampfer P (2010) Microbacterium agarici sp. nov., Microbacterium humi sp. nov.and Microbacterium pseudoresistens sp. nov., isolated from the base of the mushroom Agaricusblazei.Int J Syst Evol Microbiol 60:854-860.

\section{How to cite this article:}

Chetana Roat, Avinash Kadam, Tallika Patel and Shailesh Dave. 2016. Biodegradation of Diazo Dye, Reactive Blue 160 by Isolate Microbacterium sp. B12 Mutant: Identification of Intermediates by LC-MS. Int.J.Curr.Microbiol.App.Sci. 5(3): 534-547. doi: http://dx.doi.org/10.20546/ijcmas.2016.503.063 